\title{
Reduced Connexin-43 Expression in the Aorta of Prehypertensive Rats
}

\author{
K. DLUGOŠOVÁ ${ }^{1}$, M. MITAŠÍKOVÁ ${ }^{1}$, I. BERNÁTOVÁ ${ }^{2}$, P. WEISMANN ${ }^{3}$, \\ L. OKRUHLICOVÁ ${ }^{1}$
}

${ }^{1}$ Institute for Heart Research, Slovak Academy of Sciences, Bratislava, ${ }^{2}$ Institute of Normal and Pathological Physiology, Slovak Academy of Sciences, Centre of Excellence for Cardiovascular Research, Slovak Academy of Sciences, Bratislava, ${ }^{3}$ Medical Faculty, Comenius University, Bratislava, Slovak Republic

Received January 25, 2008

Accepted March 25, 2008

On-line March 28, 2008

\section{Summary}

Genetic component represents an important factor in the development of hypertension, which is known to be associated with changes in expression of vascular gap junction protein connexin 43 (Cx43). The aim of the study was to examine the distribution and expression of $\mathrm{Cx} 43$ in the aortic endothelium of adult normotensive Wistar rats (W), borderline hypertensive rats (BHR) and spontaneously hypertensive rats (SHR). Rings of the thoracic aorta were processed for immunofluorescence and Western blot analysis of endothelial $\mathrm{C} \times 43$ and for electron microscopy. Both, BHR and SHR exhibited significantly increased blood pressure vs. W $(132 \pm 2 \mathrm{~mm} \mathrm{Hg}$ and $185 \pm 3 \mathrm{~mm} \mathrm{Hg}$ vs. $110 \pm 2 \mathrm{~mm} \mathrm{Hg}$ ). Reduced Cx43 immunofluorescence was observed in the endothelium of BHR and these alterations were more pronounced in SHR. Western blot analysis showed significant suppression of $\mathrm{Cx} 43$ expression in the aorta of both BHR $(p<0.05)$ and SHR $(p<0.001)$ vs. W. Electron microscopy revealed local subcellular alterations of interendothelial connections in BHR including extended tight junctions. These alterations were more frequent and marked in SHR. The results indicate that connexin 43 expression is reduced in the aortic endothelium already in prehypertensive period, which may affect cell-to-cell communication and thus participate in acceleration of hypertensive disease.

\section{Key words}

Connexin 43 • Interendothelial connections • Aorta • BHR • SHR

\section{Corresponding author}

L'udmila Okruhlicová, Institute for Heart Research, Slovak Academy of Sciences, Dúbravská cesta 9, PO Box 104, 84005 Bratislava, Slovak Republic. Fax: + 42125477 6637. E-mail: usrdokru@savba.sk

\section{Introduction}

The vascular endothelium is a continuous monolayer formed by cells connected by various types of intercellular junctions that are involved in the control of endothelial permeability (Dejana et al. 1995). The structural and functional integrity of endothelium, which is promoted via the complex interaction of many substances, is essential for maintenance of tissue homeostasis as well as for regulation of vascular function. Such a versatile role of the endothelium requires coordination of the activity among individual cells, including gap junctional intercellular communication. Gap junctions are cell membrane protein channels clustered at cell-cell connections allowing exchange of ions and small molecules (up to $1 \mathrm{kDa}$ ) and thus direct intercellular communication. The properties of gap junctional channels are determined by the connexins, proteins that belong to a multigene family (Yeh et al. 2000). Disturbances in the endothelial integrity may affect cell-to-cell communication and thus signal transmission along the vessel wall (Payne et al. 2004).

Gap junctions have shown to play a significant role in many physiological mechanisms. Coupling of vascular endothelial cells as well as smooth muscle cells is thought to facilitate conduction of vasomotor responses along arteries by allowing for cell-to-cell transfer of electrical signals (Rummery and Hill 2004). Additionally, gap junctions are implicated in regulation of vascular tone (Christ et al. 1996, Chaytor et al. 1998) as well as in 
the control of vascular cell proliferation and migration (Simon and McWhorter 2003). In this regard, gap junctions may have important role in the development of the vasculature and in responses to blood vessel damage. Despite significant knowledge of connexin expression patterns in blood vessels, the contribution of specific connexins to endothelial communication is still not well understood (Krüger et al. 2002).

In the aorta, a large conduit vessel unlikely to be responsible for changes in peripheral resistance, the expression of three connexin isotypes $\mathrm{Cx} 37, \mathrm{Cx} 40$ and Cx43 was demonstrated (Van Kempen and Jongsma 1999, Haefliger et al. 2004, Rummery and Hill 2004). However, both the decrease and increase in $\mathrm{Cx} 43$ expression were reported in the aorta, depending on the experimental model of hypertension used (Watts and Webb 1996, Haefliger et al. 2004). Because the distensibility and compliance of the large artery differ among the individual models of hypertension, it was concluded that alterations in $\mathrm{Cx} 43$ expression represent an adaptive response to the changes occurring in the vascular wall during hypertension, possibly to maintain vascular elasticity (Haefliger et al. 2004).

Genetic predisposition to high blood pressure is a known risk factor for the development of hypertension and other cardiovascular diseases. Thus, normotensive animal models due to their genetic consistency need not be always appropriate for investigation of cardiovascular diseases. For such studies, a more suitable model is that of rats with a family history of hypertension, produced by the matting of spontaneously hypertensive dams with normotensive sires (Lawler et al. 1981, Bernátová et al. 2007). Since resting mean arterial pressure of adult offspring in the $F_{1}$ generation is in the range 130-150 mm $\mathrm{Hg}$, they are called borderline hypertensive rats (BHR). The advantage of the BHR model is that BHR do not develop age-related hypertension as do spontaneously hypertensive rats (Sanders and Lawler 1992) allowing to investigate the function and structure of vasculature in prehypertensive period in adulthood.

The later advantage of BHR model is especially interesting because despite a lot of information about the vascular structure (Wirth et al. 1996, Kristek et al. 2003, Okruhlicová et al. 2005, Čačányiová et al. 2006, Török et al. 2006) and connexin expression in hypertensive rats (Haefliger and Meda 2000, Haefliger et al. 2001) there is little information on pre-hypertensive period in adult rats. Therefore, we investigated the distribution and expression of gap junction protein $\mathrm{Cx} 43$ in the thoracic aorta of adult rats with borderline and fully established hypertension.

\section{Methods}

\section{Animals}

For this experiment we used 5-month-old normotensive Wistar (W) rats, borderline hypertensive rats (BHR) and spontaneously hypertensive rats (SHR). All rats were born in approved animal facility of the Institute of Normal and Pathological Physiology of Slovak Academy of Sciences. BHR were F offspring of spontaneously hypertensive (SHR) dams and normotensive Wistar (W) sires (Bernátová et al. 2007). All procedures used were approved by the State Veterinary and Food Administration of the Slovak Republic.

For morphological analysis, rats were anesthetized by thiopenthal, the thoracic aorta was excised, cleaned of adherent tissue and processed for immunofluorescence, Western blot and electron microscopy.

\section{Basic parameters}

Blood pressure (BP), heart rate (HR) (measured non-invasively by tail-cuff plethysmography using the Statham Pressure Transducer P23XL, Hugo Sachs, Germany) and body weight (BW) were determined at the end of experiment.

\section{Immunofluorescence}

For Cx43 immunolabeling, series of cryostat cross sections of non-fixed frozen aortic tissue $(10 \mu \mathrm{m})$ were preincubated with phosphate-buffered saline (PBS), fixed with $4 \%$ paraformaldehyde for $15 \mathrm{~min}$ and membranes of aortic cells were permeabilized with $0.3 \%$ Triton X-100 for $5 \mathrm{~min}$. Afterwards, sections were blocked with PBS buffer containing $1 \%$ goat serum for $30 \mathrm{~min}$ and incubated with primary monoclonal antibody mouse anti-Cx43 (1:100, Chemicon) for $2 \mathrm{~h}$ at room temperature. Sections were subsequently rinsed with PBS, followed by application of secondary antibody goat anti mouse IgG conjugated with FITC-fluorescein thioisocyanate (1:50, Chemicon). Primary antibody was omitted in negative controls. After washing aortic sections were rinsed with PBS, mounted into Vectashield mounting medium (Baria, Germany) and viewed by Axiostar fluorescent microscope (Carl Zeiss). Pictures were digitized and transferred into PC. 

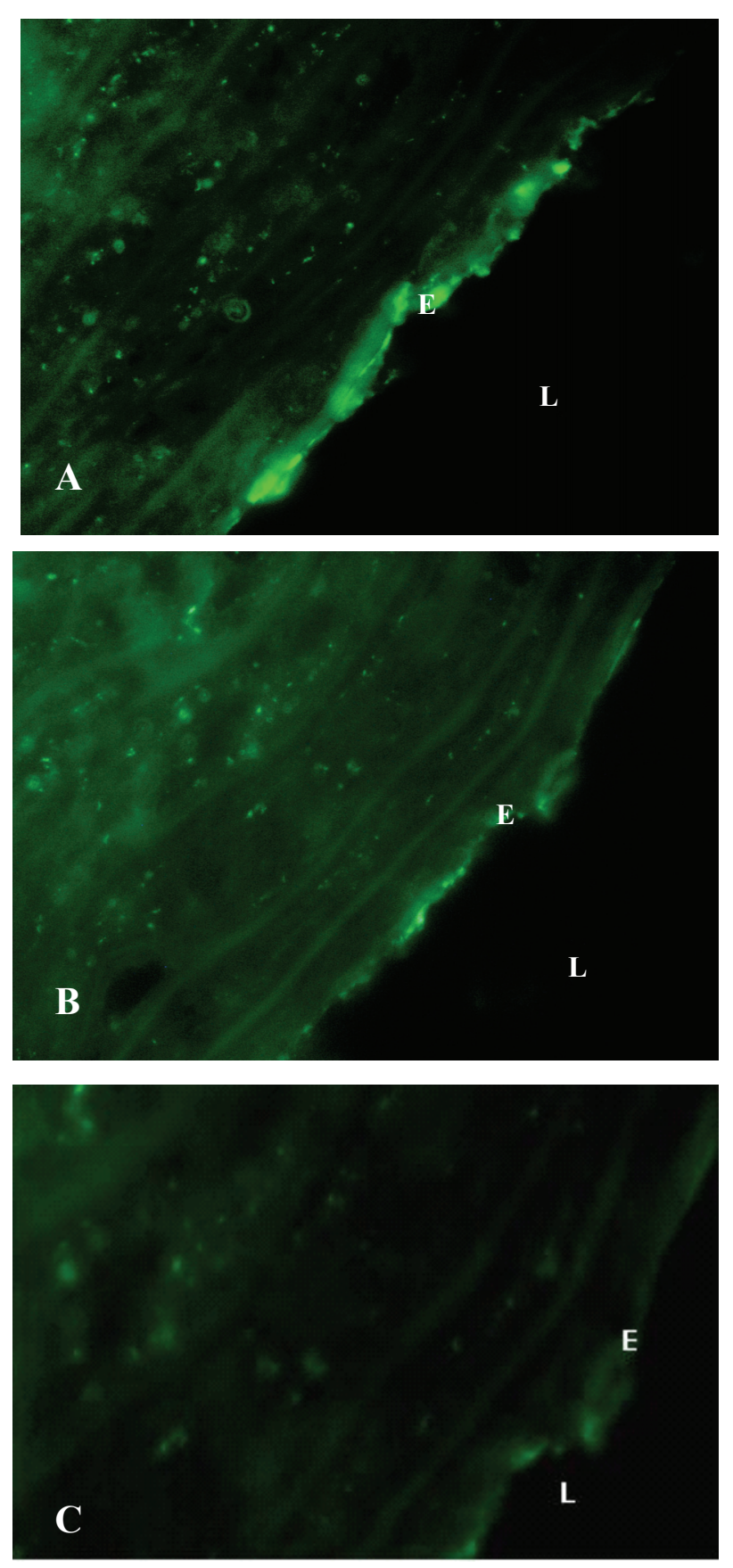

Fig. 1. Immunodetection of $\mathrm{C} x 43$ in endothelium and media of thoracic aorta of normotensive Wistar rats (A), borderline hypertensive rats (B), spontaneously hypertensive rats (C). E endothelium, $L$ - Lumen. Original magnification $80 \mathrm{x}$.

\section{Western blot analysis}

Frozen aortic tissue was homogenized in 10fold amount of $\mathrm{SB}_{20}$ solution (20\% SDS, $10 \mathrm{mmol} / 1$ EDTA, $0.1 \mathrm{~mol} / 1$ TRIS, pH 6.8) by sonificator UP $100 \mathrm{H}$ (Dr. Hielscher, Germany). Total protein content was determined by spectrophotometric method according to Bradford. Samples were fractionated by electrophoresis in $12.5 \%$ polyacrylamide gel and blotted during night onto Trans Blot Transfer Medium (Bio Rad) at a constant current $50 \mathrm{~mA}$. Membranes were preincubated for one hour at room temperature in $4 \%$ solution of dry milk in TRIS-buffered saline - TBS (20 mmol/1 Tris, $150 \mathrm{mmol} / 1 \mathrm{NaCl}, \mathrm{pH}$ 7.4-7.6), rinsed in TBS and then incubated for 2 hours in mouse monoclonal antibody to Cx43 (Sigma) that was diluted 1:1000 in blocking buffer. After immunoblots were repeatedly rinsed in TBS, they were incubated for one hour with donkey anti-mouse IgG antibody coupled with alkaline phosphatase (Promega) that was diluted 1:2000. The bands were developed with the BCIP-NBT (5-bromo-4chloro-3 indolyl phosphate/ nitro blue tetrazolium) method (Promega).

Densitometric analysis of $\mathrm{Cx} 43$ signals detected on Western blot was performed with morphometric software GelPro System (Media Cybernetics, USA).

\section{Transmission electron microscopy}

For TEM, aortae were cut into $3 \mathrm{~mm}$ rings and fixed with $2.5 \%$ glutaraldehyde in $100 \mathrm{mmol} / \mathrm{l}$ cacodylate buffer ( $\mathrm{pH}$ 7.4) for $3 \mathrm{~h}$. After washing in cacodylate buffer, tissue was postfixed in $1 \% \mathrm{OsO}_{4}$, dehydrated via ethanol series, infiltrated by propylene oxide and embedded in Epon 812. Ultra-thin sections $(65 \mathrm{~nm})$ were cut on ultramicrotome (LKB Huxley, Stockholm, Sweden), counter-stained with uranyl acetate and lead citrate, then examined in the electron microscope Tesla 500 (Brno, Czech Republic).

\section{Statistical analysis}

All results are presented as mean \pm SEM. Body weight, blood pressure and heart rate were analyzed using one-way ANOVA and followed by Duncan's post-hoc test. All other data were analyzed using oneway ANOVA and Student t-test. Values were considered to differ significantly when $\mathrm{p}<0.05$.

\section{Results}

\section{Basic parameters}

Body weight of Wistar, BHR and SHR was $309 \pm 3 \mathrm{~g}, 316 \pm 4 \mathrm{~g}$ and $287 \pm 4 \mathrm{~g}$, respectively $(\mathrm{p}<0.01$ SHR vs. W). Blood pressure of BHR and SHR was significantly increased $(\mathrm{p}<0.001)$ when compared to Wistar rats $(132 \pm 2 \mathrm{~mm} \mathrm{Hg}$ and $185 \pm 3 \mathrm{~mm} \mathrm{Hg}$ vs. $110 \pm 2$ $\mathrm{mm} \mathrm{Hg}$ ). Heart rate of Wistar rats and BHR did not differ significantly (414 \pm 11 bpm vs. $410 \pm 17$ bpm), while elevated HR was found in SHR $(452 \pm 10 \mathrm{bpm}$, $\mathrm{p}<0.05)$ vs. both Wistar and BHR. 


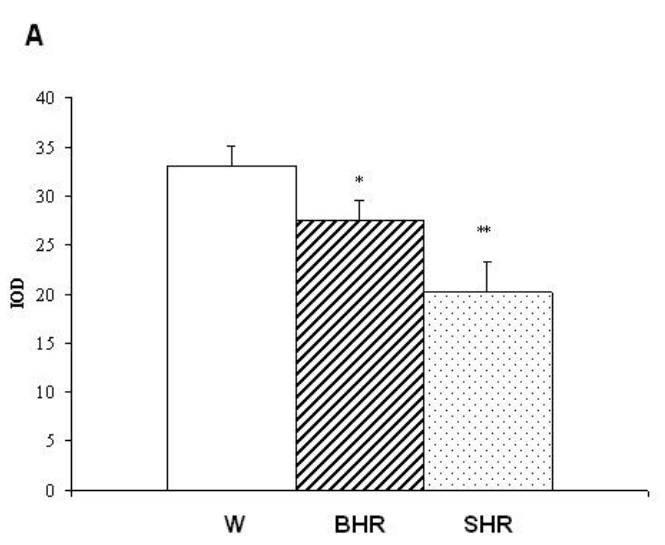

B

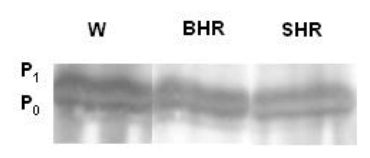

Fig. 2. A: Quantitative analysis of $C x 43$ expression in aorta of Wistar, BHR and SHR. B: Western blot showing phosphorylated $\left(P_{1}\right)$ and non-phosphorylated $\left(P_{0}\right)$ isoforms of $\mathrm{Cx} 43$ in aorta of Wistar rats (lane 1), BHR (line 2) and SHR (line 3). Values are mean \pm SEM. $* p<0.05$ vs. control, $* * p<0.001$ vs. control. IOD - integrated density, BHR - borderline hypertensive rats, SHR spontaneously hypertensive rats.

\section{Cx43 expression in the aorta}

Immunofluorescent staining of $\mathrm{Cx} 43$ showed differences in distribution between normotensive Wistar and both groups of hypertensive rats (Fig. 1). In normotensive aortae, we observed intensive punctuated Cx43 immunolabeling lining in both the endothelium and the smooth muscle cell of media (Fig. 1A). The expression pattern of $\mathrm{Cx} 43$ in the aorta of BHR showed irregular and decreased intensity of punctuated staining in the endothelium (Fig. 1B) compared to Wistar rats. In addition, immunolabeled spots of $\mathrm{Cx} 43$ were sparsely scattered through the endothelium and media of the aorta in SHR (Fig.1C).

Western blot analysis of total protein extracted from the aortae demonstrated two immunoreactive bands of $\mathrm{Cx} 43$ protein isoforms corresponding to phosphorylated (45 $\mathrm{kDa})$ and non-phosphorylated $(41 \mathrm{kDa})$ form in the aorta of all experimental groups investigated (Fig. 2). Quantitative assessment showed that the expression of total $\mathrm{Cx} 43 \quad(\sim 43 \mathrm{kDa})$ was significantly decreased in both BHR $(\mathrm{p}<0.05)$ and in SHR $(p<0.001)$ compared with normotensive controls (Fig. 2).

\section{Transmission electron microscopy}

The electron microscopy of the aortic endothelial cells of Wistar rats showed normal structure

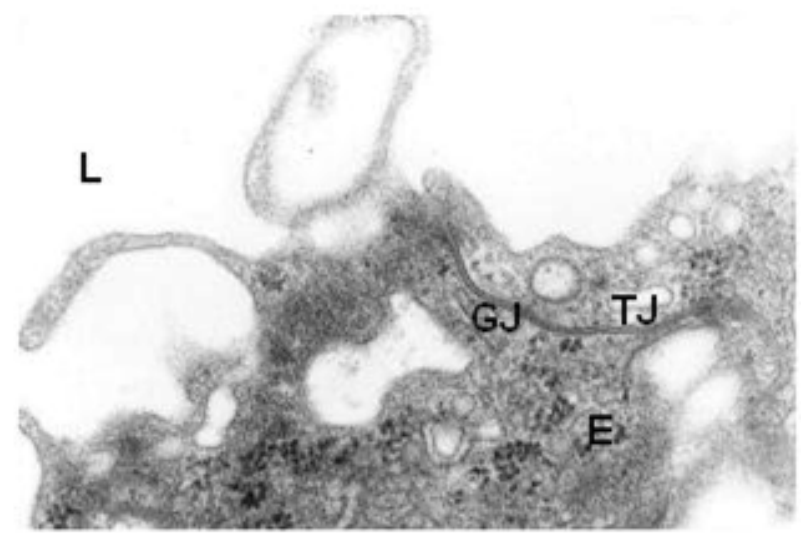

Fig. 3. Electron micrograph of end-to-end endothelial cells connection of aorta of normotensive Wistar rat formed by short gap junction (GJ) and tight junction (TJ). L - lumen. Original magnification: $32000 \mathrm{x}$.

of the endothelial gap and tight junctions (Fig. 3). On the other hand, the focal significant subcellular alterations of inter-endothelial connections in aorta of SHR were found (Fig. 4) manifested by irregular cell overlapping and extended tight junctions containing degraded membrane structures. In the aortic endothelium of BHR (Fig. 5) local irregular extended tight junctions were observed. In addition also long gap junctions connecting two adjacent cells in different stages of subcellular injury could be seen. These changes were less marked and their occurrence was less frequent than those observed in SHR.

\section{Discussion}

In the present study we demonstrated alterations of Cx43 distribution in endothelial monolayer, decreased Cx43 expression and ultrastructural alterations of endothelial gap junction and tight junctions in the aortic wall of spontaneously hypertensive rats. However, the most important finding of this study is that above mentioned changes in vascular structure of the aorta were present also in prehypertensive period. Although the occurrence and frequency of structural changes was less pronounced in prehypertensive period than in fully established hypertension, data clearly suggest that already borderline elevation of BP may be associated with impairment of endothelial monolayer followed by remodeling of vascular wall.

Arterial hypertension is one of the most important risk factors for development of other cardiovascular diseases. Despite significant research progress on the field of hypertension, the role of vascular changes in the development of hypertension is still unclear. Several authors showed significant functional 


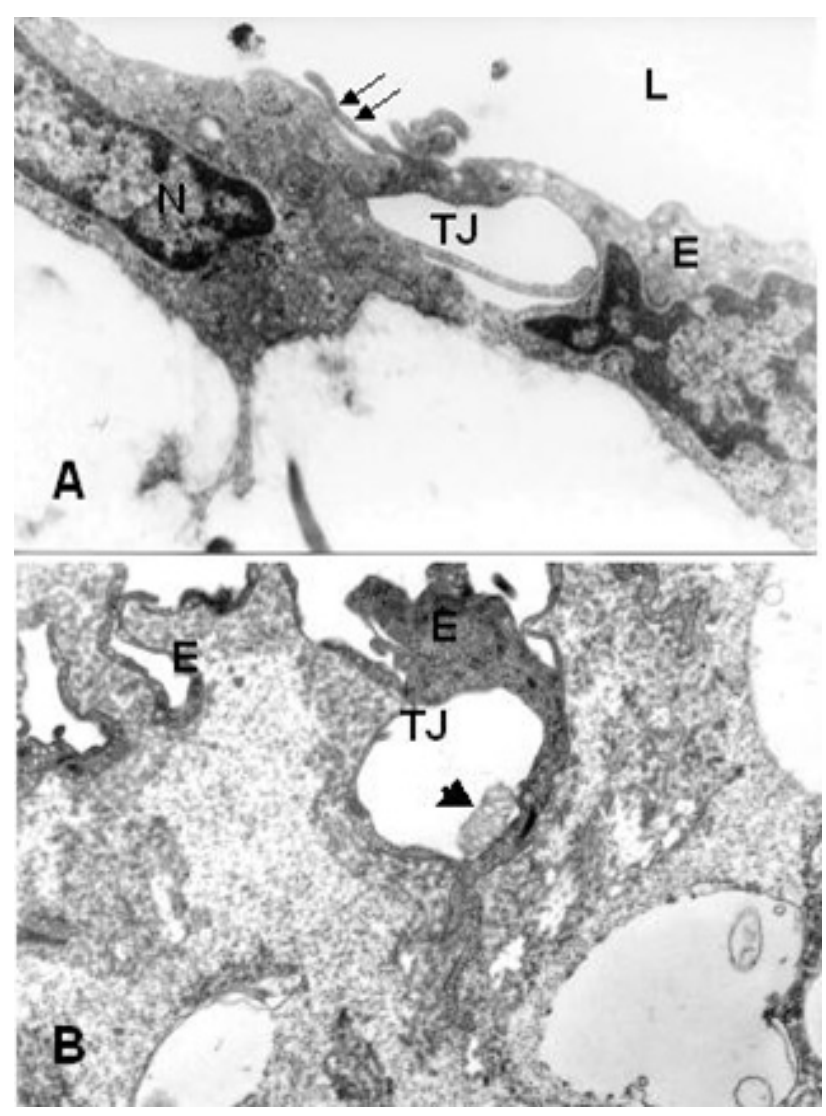

Fig. 4. Electron micrographs of endothelial cells of aorta of SHR demonstrating irregular overlapping (double arrows) and the presence of myelinized membrane structures (arrow head) in extended tight junction (TJ). E - endothelium, L - lumen. Original magnification: A 29000 x, B 30000 x.

abnormalities in the various types of blood vessels in SHR, including endothelial dysfunction (Konishi and $\mathrm{Su}$ 1983, Čačányiová et al. 2006, Török et al. 2006) while other authors, including our group, did not observe reduced endothelial function in SHR or BHR (Konishi and Su 1986, Wirth et al. 1996, Bernátová et al. 2007, Puzserová et al. 2007). On the other hand, vascular remodeling and decreased elasticity of arteries was observed in adult (Gabriels and Paul 1998, Haefliger et al. 2001, Kansui et al. 2004) as well as in young SHR (Koprdová et al. 2007). The vascular remodeling is also accompanied with increased endothelial permeability and disturbances of endothelial integrity - both determined by alterations of cell-to-cell connections including gap junctions. The aorta, which is a sparsely innervated and electrically quiescent vessel, is likely to be particularly dependent on gap junctional communications for coordinating the response of endothelial cells and smooth muscle cells to diverse signals (Christ et al. 1996). Cx43, together with $\mathrm{Cx} 37$ and $\mathrm{Cx} 40$, represent major gap junction proteins expressed in endothelium of large
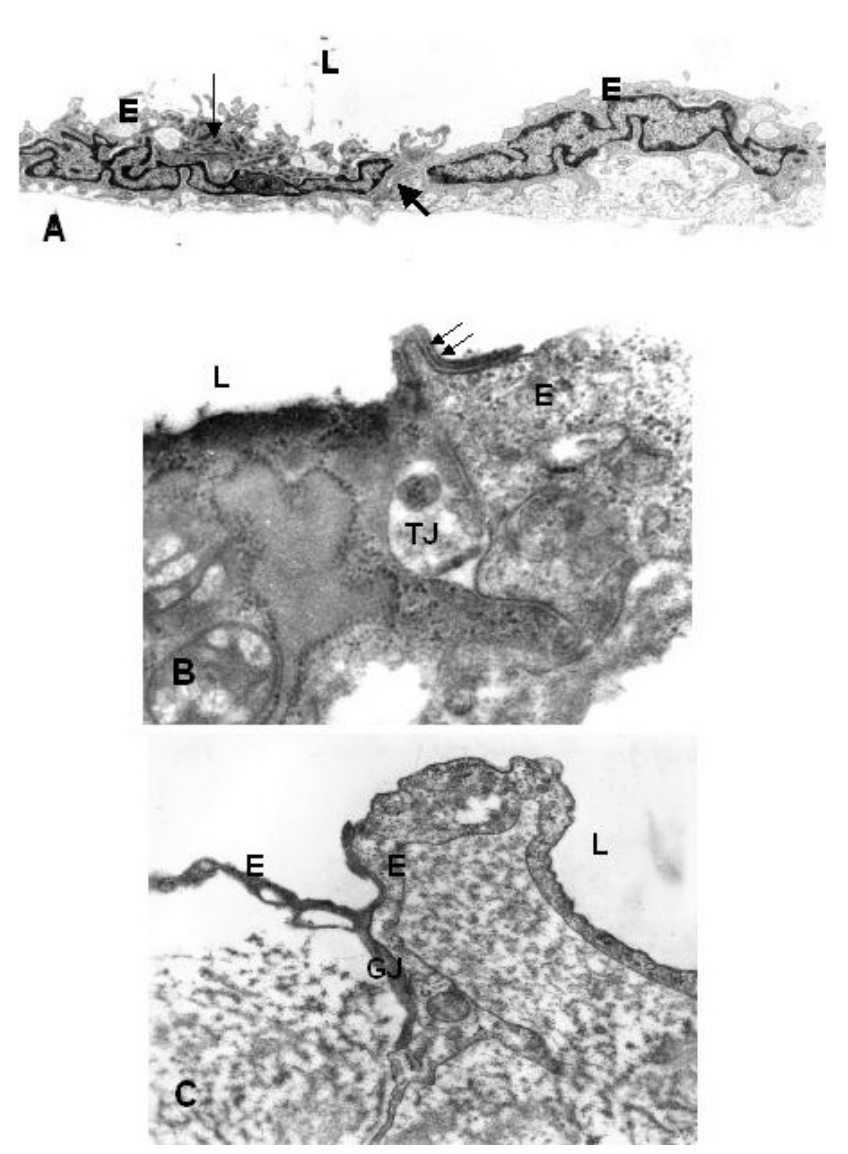

Fig. 5. A: Electron micrograph showing different subcellular injury of two adjacent endothelial cells in aorta of BHR (A) connected with extended tight junction (arrow). Small arrow indicates the increased amount of dense bodies, Weibel-Palade bodies and lysosomes. B: Structural disturbances of tight junction (TJ) and overlapping (double arrows). C: Long gap junction (GJ) connecting two endothelial cells (E) with different density of cytoplasm. L - lumen. Original magnification: A $46000 \mathrm{x}, \mathrm{B}$ 40000 x, C $38000 x$.

vessels including aorta (Bruzzone et al. 1993, Gabriels and Paul 1998). The Cx43 expression may vary depending on the species and various regions of vascular tree (Bruzzone et al. 1993, Little et al. 1995).

Several studies have reported that the high blood pressure alters connexin expression in vascular system. It is interesting that $\mathrm{Cx} 43$ expression was increased in aorta of rats made hypertensive by clipping one renal artery or in DOCA-salt model, while it was decreased in aorta of rats made hypertensive by the inhibition of NO synthase activity (Haefliger et al. 1999, Haefliger and Meda 2000). In SHR, elevated Cx43 was observed in the mesenteric artery (Kansui et al. 2004) while unchanged expression was observed in the caudal artery (Rummery et al. 2002). The above mentioned results indicate different regulation of $\mathrm{Cx} 43$ in various experimental models of hypertension and support the heterogeneity of $\mathrm{Cx} 43$ expression in the 
various parts of the vascular tree. Our finding demonstrated decreased $\mathrm{Cx} 43$ expression in the aorta already in prehypertensive rats, which was more pronounced in the aorta of rats with fully established hypertension. Suppression of Cx43 expression, together with subcellular alterations of endothelial connections in the aorta of BHR indicate that even moderately increased blood pressure may represent a risk factor affecting the intercellular communication, endothelial permeability and integrity which may consequently influence aortic function in later period of life (Wirth et al. 1996) or in interaction with other environmental factors, such as stress (Bernátová et al. 2007).

Regarding the relation between $\mathrm{Cx} 43$ and aortic function, we cannot conclude whether reduced $\mathrm{Cx} 43$ expression and junctions' morphology in the endothelium were associated with alterations in the aortic function because we did not monitor the dye transfer between endothelial cells. However, our recent study showed the ultrastructural injury of the endothelial cells in Wistarmothered BHR (Okruhlicová et al. 2007), suggesting possible impairment of endothelial function in the aorta. This impairment was supposedly related rather to EDHF- mediated responses (Kansui et al. 2004) than NO, since we observed elevated NO production in the aorta of both BHR and SHR (Bernátová et al. 2007).

In conclusion, the present study demonstrated decreased $\mathrm{Cx} 43$ expression and ultrastructural alterations of interendothelial junctions in the aorta of both BHR and SHR. The results indicate that already moderately increased blood pressure might represent a risk factor affecting interendothelial communication that may likely contribute to the further vascular wall remodeling and thus supposedly to participate in acceleration of hypertensive disease.

\section{Conflict of Interest}

There is no conflict of interest.

\section{Acknowledgements}

This study was supported by the grants of the Slovak Research and Development Agency Nos. APVT-51018004 and APVV-51-059505 and partially by VEGA grant No. 2/5021. We express our thanks to Mrs. A. Macsaliová, I. Macková, J. Pet’ová and Y. Hanáčková for their skilful technical assistance.

\section{References}

BERNÁTOVÁ I, CSIZMÁDIOVÁ Z, KOPINCOVÁ J, PUZSEROVÁ A: Vascular function and nitric oxide production in chronic social-stress-exposed rats with various family history of hypertension. $J$ Physiol Pharmacol 58: 487-501, 2007.

BRUZZONE R, HAEFLIGER JA, GIMLICH RL, PAUL DL: Connexin 40: a component of gap junctions in vascular endothelium, is restricted in its ability to interact with other connexins. Mol Biol Cell 4: 7-20, 1993.

ČAČÁNYIOVÁ S, CEBOVÁ M, KUNEŠ J, KRISTEK F: Comparison of vascular function and structure of iliac artery in spontaneously hypertensive and hereditary hypertriglyceridemic rats. Physiol Res 55 (Suppl 1): S73-S80, 2006.

CHAYTOR AT, EVANS WH, GRIFFITH TM: Central role of heterocellular gap junctional communication in endothelium-dependent relaxations of rabbit arteries. J Physiol Lond 508: 561-573, 1998.

CHRIST GJ, SPRAY DC, EL SABBAN M, MOORE LK, BRINK PR: Gap junctions in vascular tissues: evaluating the role of intercellular communication in the modulation of vasomotor tone. Circ Res 79: 631-646, 1996.

DEJANA E, CORADA M, LAMPUGNANI MG: Endothelial cell-to-cell junctions. FASEB J 9: 910-918, 1995.

GABRIELS JE, PAUL DL: Connexin 43 is highly localized to sites of distributed flow in rat aortic endothelium but connexin 37 and connexin 40 are more uniformly distributed. Circ Res 83: 636-643, 1998.

HAEFLIGER JA, MEDA P: Chronic hypertension alters the expression of Cx43 in cardiovascular muscle cells. Braz $J$ Med Biol Res 33: 431-438, 2000.

HAEFLIGER JA, MEDA P, FORMENTON A, WIESEL P, ZANCHI A, BRUNNER HR, NICOD P, HAYOZ D: Aortic connexin 43 is decreased during hypertension induced by inhibition of nitric oxide synthase. Arterioscler Thromb Vasc Biol 19: 1615-1622, 1999.

HAEFLIGER JA, DEMOTZ S, BRAISSANT O, SUTER E, WAEBER B, NICOD P, MEDA P: Connexins 40 and 43 are differently regulated within the kidneys of rats with renovascular hypertension. Kidney Int 60: 190-201, 2001. 
HAEFLIGER JA, NICOD P, MEDA P: Contribution of connexins to the function of the vascular wall. Cardiovasc Res 62: 345-356, 2004.

KANSUI Y, FUJII K, NAKAMURA K, GOTO K, INIKI H, ABE I, SHIBATA Y, IIDA M: Angiotensin II receptor blockade corrects altered expression of gap junction in vascular endothelial cells from hypertensive rats. $\mathrm{Am} J$ Physiol 287: H216-H224, 2004.

KONISHI M, SU C: Role of endothelium in dilator responses of spontaneously hypertensive rat arteries Hypertension 5: 881-886, 1983.

KOPRDOVÁ R, CEBOVÁ M, KRISTEK F: Effect of prazosin on geometry and structure of the coronary artery in SHR. In: Proceedings of Genetic and Environmental Factors in Hypertension 2007. I BERNÁTOVÁ (ed), Bratislava, 2007, pp 115-120.

KRISTEK F, FABEROVÁ V, VARGA I: Long-term effect of molsidomine and pentaerythril tetranitrate on cardiovascular system of spontaneously hypertensive rats. Physiol Res 52: 709-717, 2003.

KRÜGER O, BENY JL, CHABAUD F, TRAUB O, THEIS M, BRIX K, KIRCHOFF S? WILLECKE K: Altered dye diffusion and upregulation of connexin 37 in mouse aortic endothelium deficient in connexin40. $J$ Vasc Res 39: 160-172, 2002.

LAWLER GF, BARKER JW, HUBBARD JW, SCHAUB RG: Effects of stress on blood pressure and cardiac pathology in rats with borderline hypertension. Hypertension 3: 495-505, 1981.

LITTLE TL, BEYER EC, DULING BR: Connexin 43 and connexin 40 gap junctional proteins are present in arterial smooth muscle and endothelium in vivo. Am J Physiol 268: H729-H739, 1995.

OKRUHLICOVÁ L', TRIBULOVÁ N, WEISMANN P, SOTNÍKOVÁ R: Ultrastructure and histochemistry of rat myocardial capillary endothelial cells in response to diabetes and hypertension. Cell Res 15: 532-538, 2005.

OKRUHLICOVÁ L', DLUGOŠOVÁ K, MITAŠÍKOVÁ-FIALOVÁ M, BERNÁTOVÁ I: Ultrastructural characteristics of aortic endothelial cells in borderline hypertensive rats exposed to chronic social stress. Physiol Res $\mathbf{5 7}$ (Suppl 2): S31-S37, 2008.

PAYNE GW, MADRI JA, SESSA WC, SEGAL SS: Histamine inhibits conducted vasodilation through endotheliumderived NO production in arterioles of mouse skeletal muscle. FASEB $J$ 18: 280-286, 2004.

PUZSEROVÁ A, CSIZMÁDIOVÁ Z, BERNÁTOVÁ I: Effect of blood pressure on L-NAME-sensitive component of relaxation in adult rats. Physiol Res $\mathbf{5 6}$ (Suppl 2): S77-S84, 2007.

RUMMERY NM, HILL CE: Vascular gap junctions and implications for hypertension. Clin Exp Pharmacol Physiol 31: 659-667, 2004.

RUMMERY NM, MCKENZIE KU, WHITWORTH JA, HILL CE: Decreased endothelial size and connexin expression in rat caudal arteries during hypertension. $J$ Hypertens 20: 247-253, 2002.

SANDERS BJ, LAWLER JE: The borderline hypertensive rat (BHR) as a model for environmentally-induced hypertension: a review and update. Neurosci Biobehav Rev 16: 207-217, 1992.

SIMON AM, MCWHORTER AR: Decreased intercellular dye-transfer and downregulation of non-ablated connexins in aortic endothelium deficient in connexin 37 or connexin 40. J Cell Sci 116: 2223-2236, 2003.

TÖRÖK J, KOPRDOVÁ R, CEBOVÁ M, KUNEŠ J, KRISTEK F: Functional and structural pattern of arterial responses in hereditary hypertriglyceridemic and spontaneously hypertensive rats in early stages of experimental hypertension. Physiol Res 55 (Suppl 1): S65-S71, 2006.

VAN KEMPEN MJA, JONGSMA HJ: Distribution of connexin 37, connexin 40 and connexin 43 in the aorta and coronary artery of several mammals. Histochem Cell Biol 112: 479-486, 1999.

WATTS SW, WEBB RC: Vascular gap junctional communication is increased in mineralocorticoid-salt hypertension. Hypertension 28: 888-893, 1996.

WIRTH KJ, LINZ W, WIEMER G, SCHÖLKENS BA: Differences in acetylcholine- and bradykinin-induced vasorelaxation of the mesenteric vascular bed in spontaneously hypertensive rats of different ages. NaunynSchmiedeberg's Arch Pharmacol 354: 38-43, 1996.

YEH HI, CHANG HM, LU WW, LEE YN, KO YS, SEVERS NJ, TSAI CH: Age-related alteration of gap junction distribution and connexin expression in rat aortic endothelium. J Histochem Cytochem 48: 1377-1390, 2000. 